\title{
Hydrogeochemical processes and chemical characteristics around Sahand Mountain, NW Iran
}

\author{
Kaveh Pazand $\cdot$ Ardeshir Hezarkhani
}

Received: 18 August 2012/Accepted: 3 March 2013/Published online: 15 March 2013

(C) The Author(s) 2013. This article is published with open access at Springerlink.com

\begin{abstract}
The chemical analysis of 21 water wells in Sahand area, NW of Iran has been evaluated to determine the hydrogeochemical processes and ion, heavy and trace metal concentration background in the region. The dominated hydrochemical types are $\mathrm{Ca}-\mathrm{Mg}-\mathrm{HCO}_{3}, \mathrm{Ca}-\mathrm{SO}_{4}$ and $\mathrm{Na}-\mathrm{Cl}$ that vary in different group sample. The $\mathrm{pH}$ and $\mathrm{Eh}$ of the groundwater in the study area indicating an acidic to alkaline nature of the samples in group II, acidic nature in group I and neutral in group III. Also in Group III than Group I and II, the oxidizing condition is dominant, while in the other groups relative reducing conditions prevail. Due to $\mathrm{Cu}$ and other metal mineralization in I and II site, $\mathrm{Cu}, \mathrm{As}, \mathrm{Au}$ and other metal concentration in this water groups is higher than group III.
\end{abstract}

Keywords Hydrogeochemical - Sahand · Groundwater . Metal concentration - Water groups · Oxide condition

\section{Introduction}

Poor groundwater quality has attracted worldwide attention particularly because of increasing dependence on groundwater as a source of water for securing the quality of life. Variation in groundwater chemistry is mainly a function of the interaction between the groundwater and the mineral composition of the aquifer materials through which it

\section{K. Pazand ( $\square)$}

Mahabad 2 Center, University of Applied Science

and Technology, Mahabad, Iran

e-mail: kaveh.pazand@gmail.com; kavehpazand@yahoo.com

\section{A. Hezarkhani}

Department of Mining, Metallurgy and Petroleum Engineering, Amirkabir University, Hafez Ave. No. 424, Tehran, Iran moves (Sharif et al. 2008). Aqueous geochemistry (including ground and surface water and stream sediments) has been applied successfully in environmental studies and mineral exploration for some time (Valles et al. 1989; Rango et al. 2010). In the past few decades, many hydrogeochemical studies have addressed the Arsenic problem to elucidate its origin (Welch et al. 1988; Webster and Nordstrom 2003; Guo et al. 2010) and to investigate the associated health problems. The importance of water quality in human health has recently attracted a great deal of interest (Pazand et al. 2011). The evaluation and management of groundwater resources require an understanding of hydrogeological and hydrochemical properties of the aquifer. The importance of the groundwaters in the area is high because they are water resource for drinking and agricultural purposes. In the study area, agriculture is the most important economic activity, thus hydrogeochemical investigation was carried out to identify groundwater geochemistry in the area.

\section{Materials and methods}

Geological settings

The study area is located within the boundaries of the district in Azarbaijan province in northern west Iran which is structurally part of the Urumieh-Dokhtar unit. Continental collision between the Afro-Arabian continent and the Iranian microcontinent during closure of the Tethys ocean in the late Cretaceous resulted in the development of a volcanic arc in NW Iran (Mohajjel and Fergusson 2000; Karimzadeh 2005). In Iran, all known copper mineralization occurs in the Cenozoic Urumieh-Dokhtar orogenic belt. This belt was formed by subduction of the Arabian 
plate beneath central Iran during the Alpine orogeny (Berberian and King 1981; Pourhosseini 1981). The area includes formations of Devonian to Quaternary age affected by various geologic movements, most strongly by those of Alpine origin.

In the Pliocene epoch, there was a marine regression and a change to continental conditions, mainly lacustrine, coupled with the deposition of clay and clastics. Then, the Plio-Pleistocene marked significant volcanic activity, with lava flows and pyroclastic masses associated with the continental conditions of that epoch. Hence, the southern part of the Tabriz area is occupied by the extinct Sahand volcano, which is built up from volcanic rocks. This massif is surrounded by volcanic sediments and alluvial tuff. The Sahand alluvial tuff conformably overlies Pliocene marls, sandstones and fish bed layers. The Plio-Pleistocene volcanic tuffs have an extended exposure over $1,000 \mathrm{~km}^{2}$ in the study area and conformably overlie the Pliocene beds to the south of the Tabriz Plain around the core of the Sahand volcano (Moghaddam and Najib 2006). The alluvial tuff formation is composed mainly of red and green andesitic tuff admixed with large quantities of blocks, boulders, gravel and sand of volcanic and alluvial origin. Its thickness varies from a few tens of meters at the northern end of the Sahand Mountain to possibly over $500 \mathrm{~m}$ in the south. In some places, these formations are separated by a local low-permeability conglomerate or agglomerate horizon (Moghaddam and Najib 2006). The main lithology in northeastern part of the study area is Oligocene-aged intrusive rocks (Razgah monzosyenite to monzodiorite) that have copper mineralization as malachite. The northern parts of the study area are covered by the Miocene-Pliocene sandstone and siltstone. The gypsiferous marl and limestone area spread in all area (Mahdavi and Fazl 1988). The Miocene-Pliocene rhyolite-dacitic volcanic rocks mainly observe in the northeast, southeast and central area. Evidence of copper mineralization in sandstone rocks of northern Sahand is seen as malachite. The quaternary alluviums cover the dominant of study area (Tehrani and Lotfi 1978) (Fig. 1).

Sampling and geochemical analyses

Twenty-one groundwater samples were collected at three sites (I, II, III) in study area in November 2008) Fig. 1). Groundwater samples were collected following the standard procedures (Halim et al. 2009) which included: (1) filtered using $0.45 \mu \mathrm{m}$ filters and acidified with supra pure $0.7 \mathrm{~N}$ HNO3 to $\mathrm{pH}<2$ for the analysis of heavy and trace elements, (2) filtered but not acidified for the analysis of major ions and, (3) not filtered and not acidified for the analysis of carbonates and bicarbonates. The samples were collected in
$100 \mathrm{~mL}$ Polyethylene bottles, after pumping continuously 15-30 min until the temperature, electrical conductivity (EC) and $\mathrm{pH}$ reading had stabilized. Immediately after sampling, $\mathrm{pH}$, temperature and EC were measured in the field using a portable $\mathrm{pH}$ meter. Samples were analyzed in the laboratory for the major ions employing standard methods. Calcium $\left(\mathrm{Ca}^{2+}\right)$ and magnesium $\left(\mathrm{Mg}^{2+}\right)$ were determined titrimetrically using standard EDTA. Chloride $\left(\mathrm{Cl}^{-}\right)$was determined by standard $\mathrm{AgNO}_{3}$ titration method. Carbonate $\mathrm{CO}_{3}^{2-}$ and bicarbonate $\left(\mathrm{HCO}_{3}^{-}\right)$were determined by titration with $\mathrm{HCl}$. Sodium $\left(\mathrm{Na}^{+}\right)$and potassium $\left(\mathrm{K}^{+}\right)$ were measured by flame photometry, sulfate $\mathrm{SO}_{4}^{2-}$ by spectrophotometric turbidimetry, and $\mathrm{NO}_{3}^{-}$by colorimetry with an UV-visible spectrophotometer (Rowell 1994). Total dissolved solids (TDS) were determined gravimetrically at $105-110^{\circ} \mathrm{C}$ (Table 1 ).

Major and trace elements were measured with inductively coupled plasma and mass spectrometry (ICP-MS) in the filtered and acidified water samples within 2 weeks after sampling (Table 2).

\section{Results and discussions}

\section{General hydrogeochemistry}

The results of chemical compositions of the groundwater samples are given in Table 1. Major cation and anion concentrations vary in these three site areas. The concentrations of $\mathrm{Ca}^{2+}, \mathrm{Mg}^{2+}, \mathrm{Na}^{+}$, and $\mathrm{K}^{+}$represent on average $26.74,11.07,59.36$, and $2.83 \%$ of all the cations in group (I) (sample 1-9), 13.97, 12.51, 71.82 and $1.7 \%$ of all the cations in group (II) (sample 10-15), 53.46, 7.62, 37.74 and $1.18 \%$ of all the cations in group (III) (sample 16-21), respectively. Among the anions, the concentrations of $\mathrm{HCO}_{3}^{-}, \mathrm{Cl}^{-}, \mathrm{SO}_{4}^{2-}$, and $\mathrm{NO}_{3}^{-}$represent on average 32.4, $23,43.48$, and $1.12 \%$ in group (I), 17.01, 31.79, 50.24, and $0.096 \%$ in group (II) and 48.31, 20.14, 26.48, and $4.71 \%$ in group (III), respectively. Thus, the order of cation and anion abundance is:

$$
\begin{aligned}
\text { Group I }: \mathrm{Na}^{+}>\mathrm{Ca}^{2+}>\mathrm{Mg}^{2+}>\mathrm{K}^{+} \\
\mathrm{SO}_{4}^{2-}>\mathrm{HCO}_{3}^{-}>\mathrm{Cl}^{-}>\mathrm{NO}_{3}^{-} \\
\text {Group II : } \mathrm{Na}^{+}>\mathrm{Ca}^{2+}>\mathrm{Mg}^{2+}>\mathrm{K}^{+} \\
\mathrm{SO}_{4}^{2-}>\mathrm{Cl}^{-}>\mathrm{HCO}_{3}^{-}>\mathrm{NO}_{3}^{-} \\
\text {Group III }: \mathrm{Ca}^{2+}>\mathrm{Na}^{+}>\mathrm{Mg}^{2+}>\mathrm{K}^{+} \\
\mathrm{HCO}_{3}^{-}>\mathrm{SO}_{4}^{2-}>\mathrm{Cl}^{-}>\mathrm{NO}_{3}^{-}
\end{aligned}
$$

A scatter distribution of groundwater samples on Piper diagram suggests a wide variation in the hydrochemical facies in study area (Fig. 2). The groundwater samples fall 


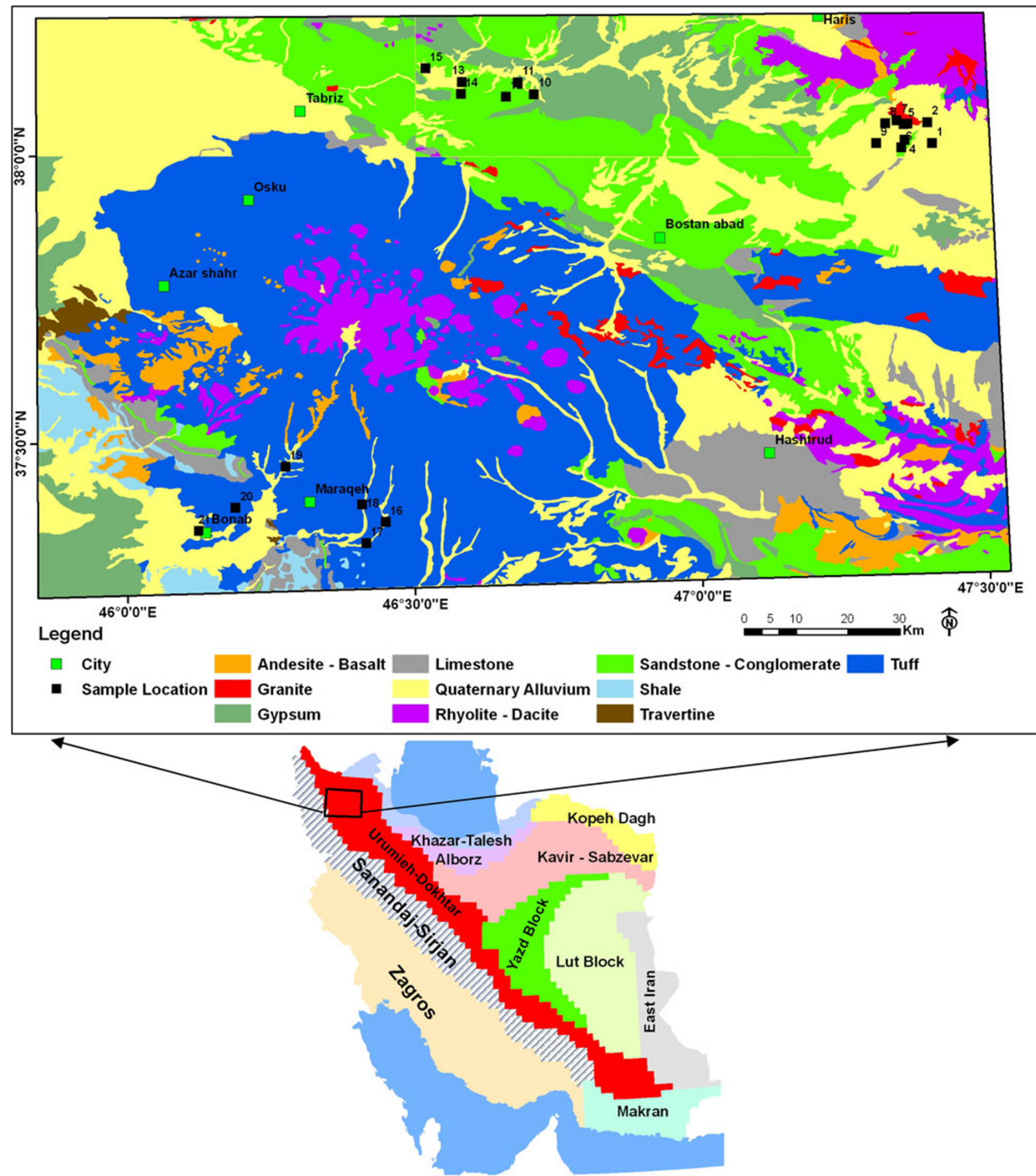

Fig. 1 Major structural zones of Iran (after Nabavi 1976) and the location of study area in these zones and a modified and simplified geologic map of it (after Tehrani and Lotfi 1978; Shahrabi 1985; Mahdavi and Amini Fazl 1988)

in three of major water type fields representing (1) $\mathrm{Ca}-\mathrm{Mg}-$ $\mathrm{HCO}_{3}$, (2) $\mathrm{Ca}-\mathrm{SO}_{4}$ and (3) $\mathrm{Na}-\mathrm{Cl}$ facies.

In the group (I) samples $\mathrm{Na}-\mathrm{Cl}$ and $\mathrm{Ca}-\mathrm{SO}_{4}$ each represent 67 and $33 \%$ of the total of water samples analysed in group. In group (II) $\mathrm{Na}-\mathrm{Cl}$ and $\mathrm{Ca}-\mathrm{SO}_{4}$ represent 83.33 and $16.67 \%$ of the total of water samples analysed in group, respectively. In the group (III) $\mathrm{Ca}-\mathrm{Mg}-\mathrm{HCO}_{3}$ type is dominant as it includes $66.66 \%$ of samples, whereas $\mathrm{Na}-\mathrm{Cl}$ and $\mathrm{Ca}-\mathrm{SO}_{4}$ each represents $16.67 \%$ of the total of water samples analysed in group (Fig. 3). 


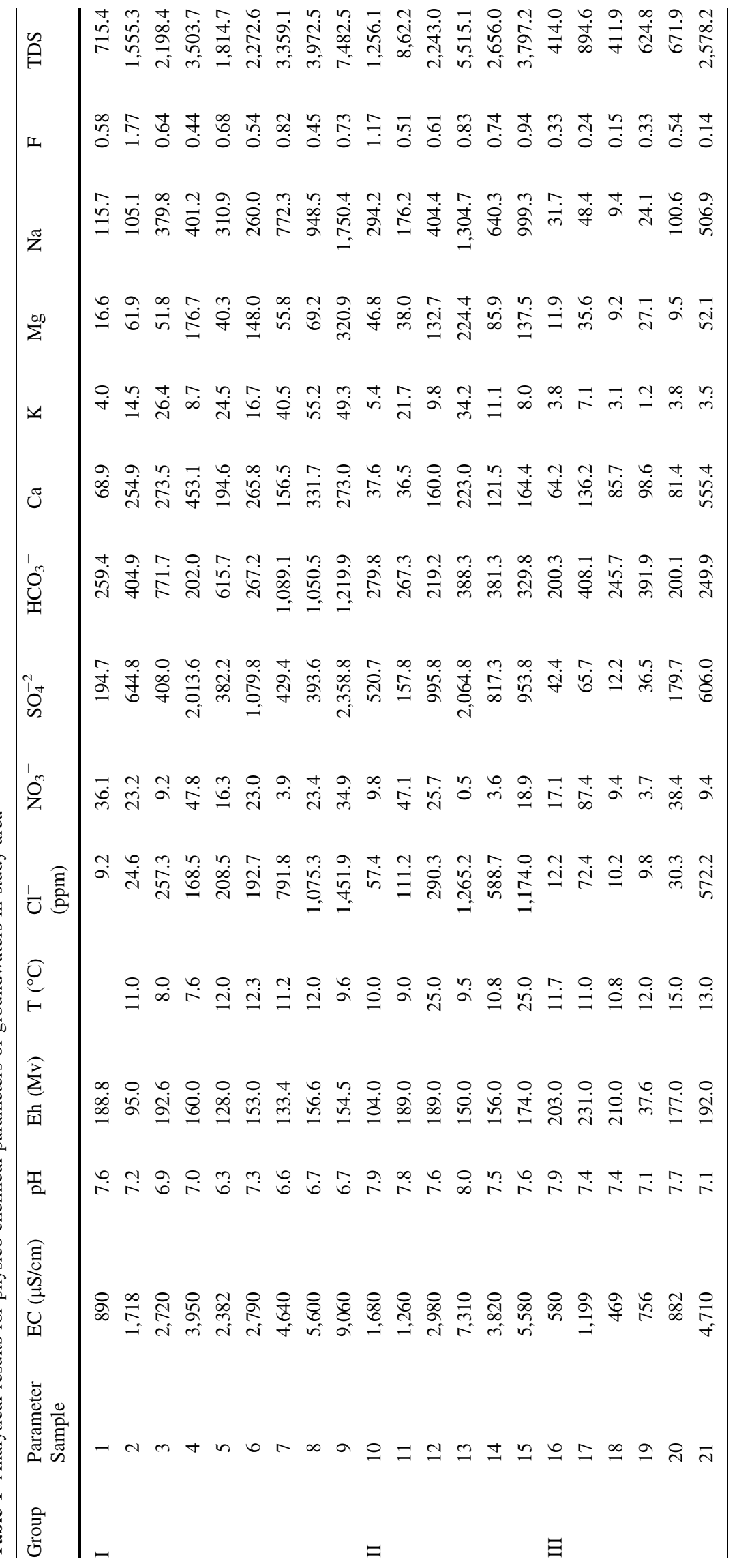




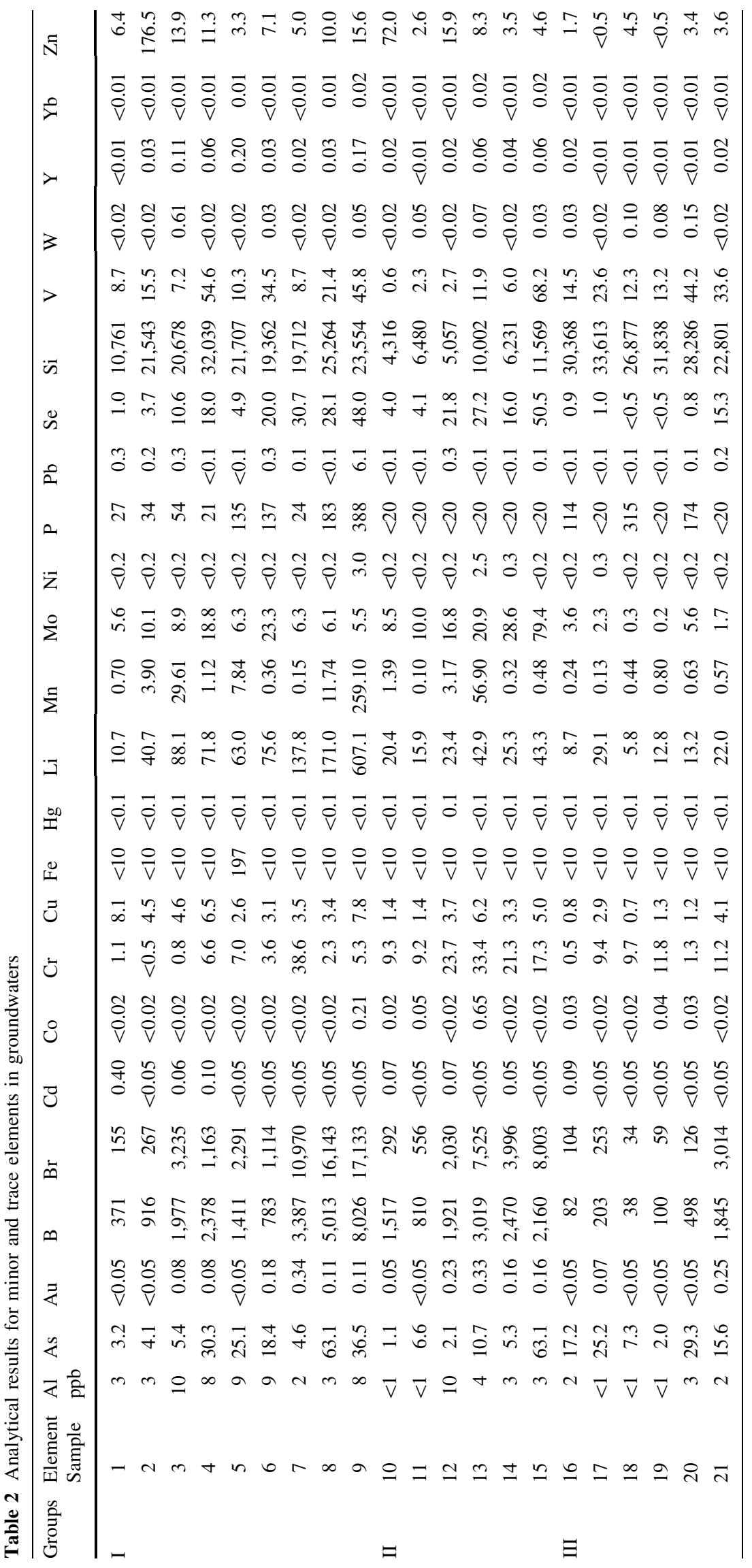


Fig. 2 The piper diagram for the groundwater samples of the study area

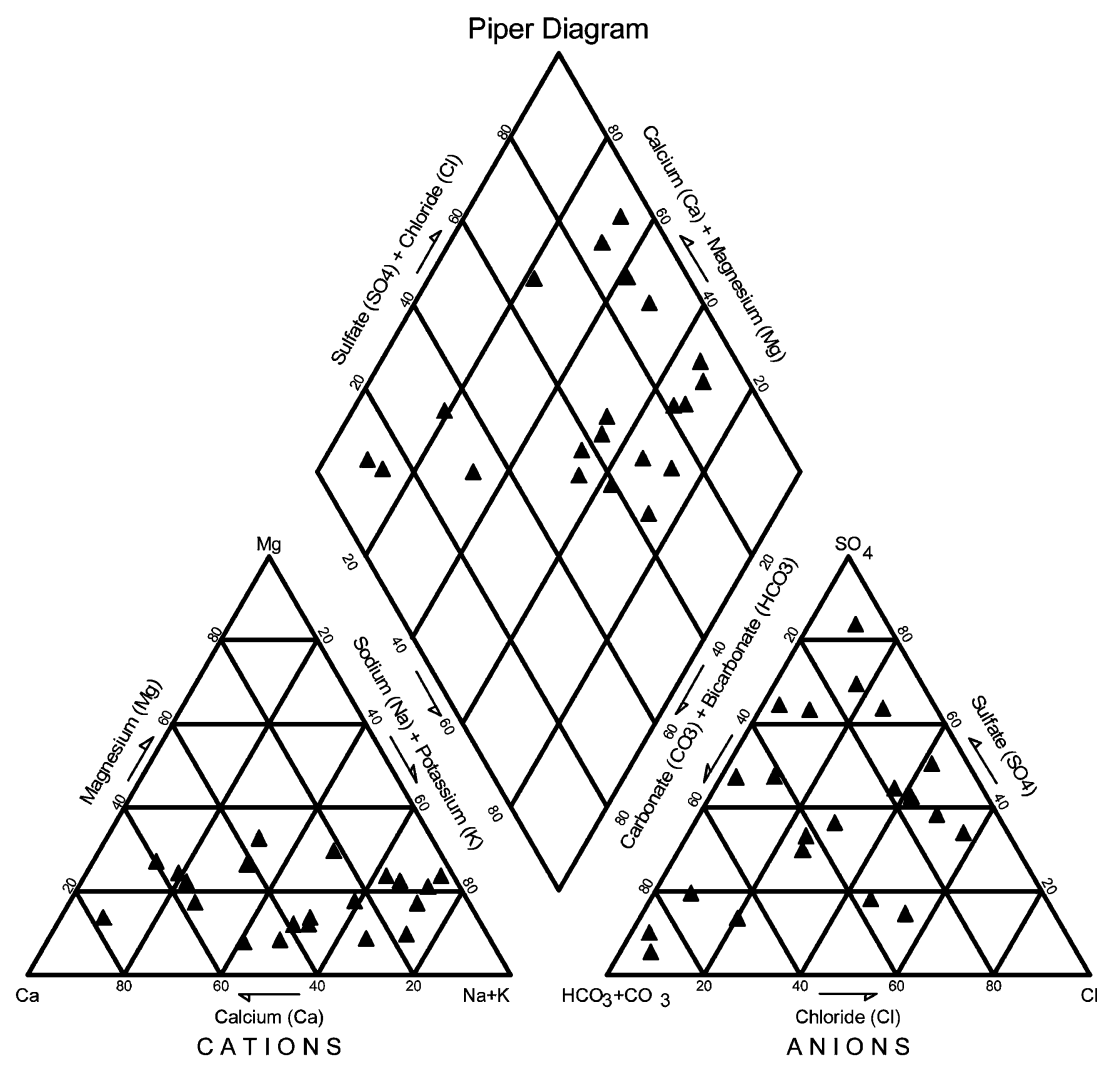

The binary diagram of Fig. 4 illustrates the relationship between $\mathrm{pH}$ and Eh in different group waters. Redox state of groundwater has differed in three groups.

The $\mathrm{pH}$ of the groundwater in the study area ranged from 6.34 to 8 (Fig. 4), indicating an alkaline nature of the samples in group II, acidic nature in group I and natural in group III. Measured Eh values also indicate fluctuating redox conditions. The Eh can be used with other redox indicators to ascertain, in a qualitative sense, the relative redox conditions of an aquifer (Smedley and Edmunds 2002). Accordingly, Eh measured in relatively oxidizing conditions are in groundwater with relative increasing oxidization conditions in group III. TDS is an important parameter that can be used to observe the influence of major components in groundwater quality.TDS concentration in group III is higher than other groups, with mean TDS contents of $934 \mathrm{ppm}$. If halite dissolution is responsible for sodium, $\mathrm{Na}^{+} / \mathrm{Cl}^{-}$ratio should be approximately equal to 1 , whereas ratio greater than 1 is typically interpreted as Na released from silicate weathering reaction (Meyback 1987). In the present study, samples had $\mathrm{Na}^{+} / \mathrm{Cl}^{-}$ratio greater and lower than 1 (Fig. 5) and hence, mixing of silicate weathering and halite dissolution was the probable source of sodium. Some sodium may be derived from Na-bearing silicate minerals, such as albite. Weathering of albite produces kaolinite and $\mathrm{Na}^{+}$ions. This reaction would result in a
$\mathrm{Si} /(\mathrm{Na}-\mathrm{Cl})$ of \pm 2 . The $\mathrm{Si} /(\mathrm{Na}-\mathrm{Cl})$ ratio encountered in the study area is generally lower than 2 (Fig. 5). As no silicate weathering reaction could explain such low ratios (Stallard and Edmond 1987), the excess $\mathrm{Na}^{+}$is probably not derived solely from silicate weathering (excepts sample 16 and 19). Molar ratio of $\mathrm{Cl}^{-}$and bicarbonate $\left(\mathrm{HCO}_{3}{ }^{-}\right)$is used to distinguish between freshwater and saline water. Seawater have very high $\mathrm{Cl}^{-} / \mathrm{HCO}_{3}{ }^{-}$molar ratio $(>200)$ while fresh water usually shows $\mathrm{Cl}^{-} / \mathrm{HCO}_{3}{ }^{-}$ $<1$ and molar ratio of $\mathrm{Cl}^{-} / \mathrm{HCO}_{3}{ }^{-}>1$ indicates mixing of seawater with fresh water (Raghunath 1987; Aziz Hasan et al. 2009). Plots of molar $\mathrm{Cl}^{-} / \mathrm{HCO}_{3}{ }^{-}$(Fig. 5) show that a significant number of samples in the Group II have $\mathrm{Cl}^{-}$/ $\mathrm{HCO}_{3}{ }^{-}>1$ indicating seawater mixing, but majority of the samples in the group I of samples have $\mathrm{Cl}^{-} / \mathrm{HCO}_{3}{ }^{-}$ $<1$ indicating freshwater. The chloro-alkaline index, $\mathrm{CAI}=[\mathrm{Cl}-(\mathrm{Na}+\mathrm{K})] / \mathrm{Cl}$, is suggested by Schoeller (1977), which indicates the ion exchange between the groundwater and its host environment. If there is ion exchange of $\mathrm{Na}^{+}$and $\mathrm{K}^{+}$from water with magnesium and calcium in the rock, the exchange is known as direct when the indices are positive. If the exchange is reverse then the exchange is indirect and the indices are found to be negative. The negative CAI values in study area suggest that magnesium and calcium from water are exchanged with sodium and potassium in rock favoring cation-anion exchange reactions (Fig. 5). 


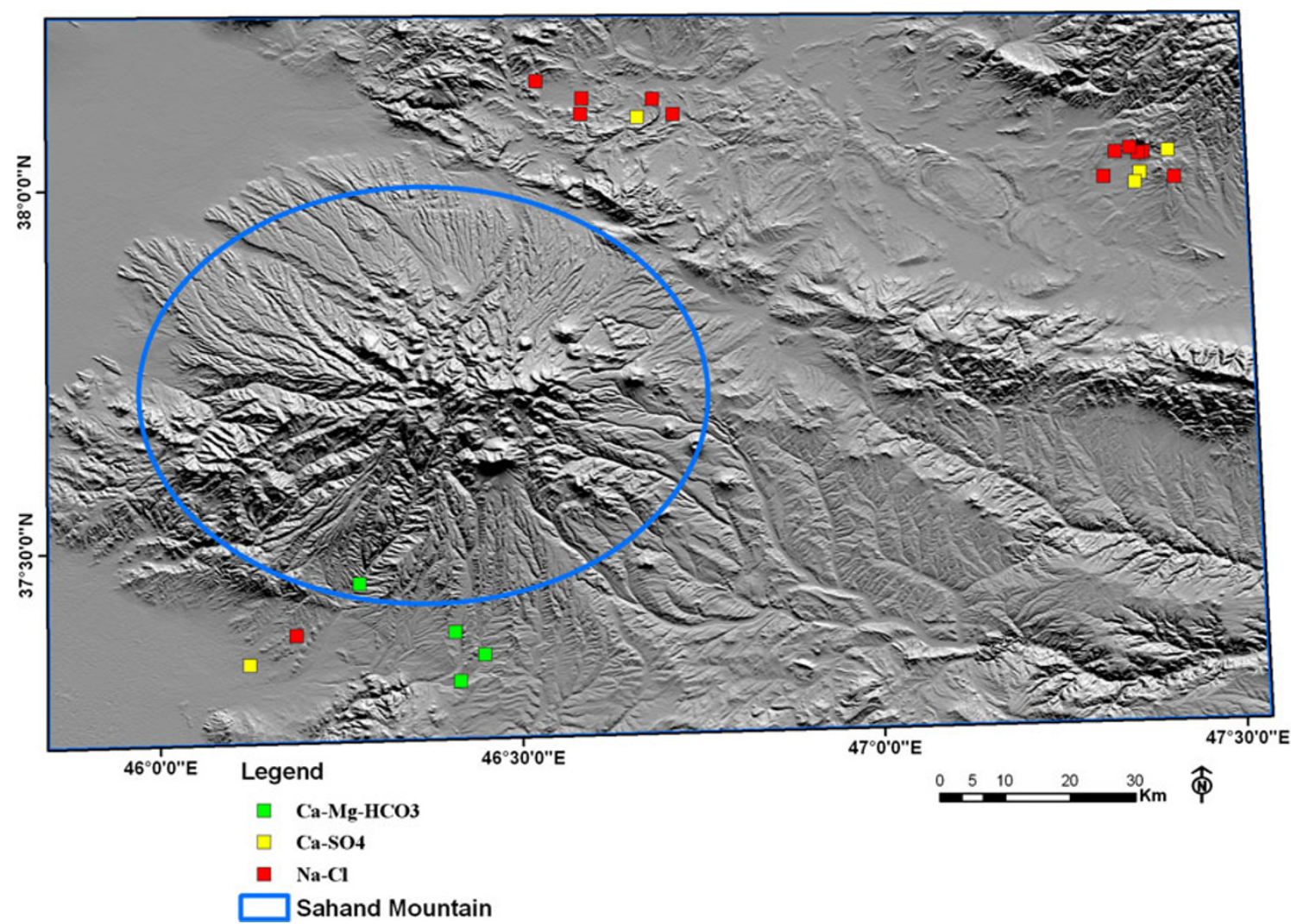

Fig. 3 Distribution of water types in the groundwater of the study area
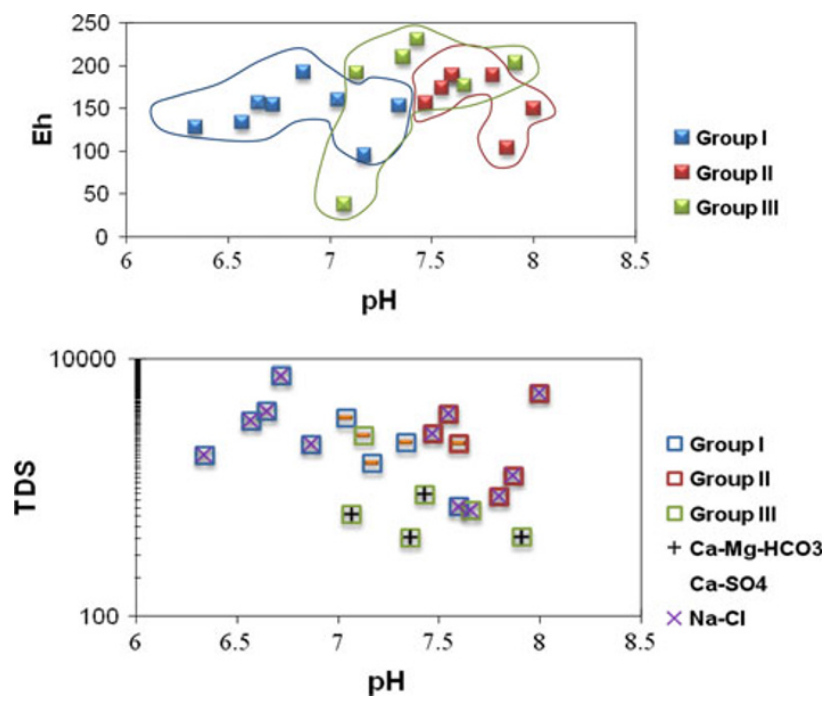

Fig. 4 Diagrams shown the relationships of Eh and TDS versus $\mathrm{pH}$ in different water sample in study area

Trace metals in groundwater

Concentration of metals in groundwater is presented in Table 2. Redox state of groundwater has been shown to be a primary control of As, Au, Se and V (Fig. 6).
In many example, arsenic and other elements that form oxyanions are released from $\mathrm{Fe}$ and $\mathrm{Mn}$ oxides by desorption (Acharyya et al. 2000; Smedley and Edmunds 2002; Mukherjee et al. 2008). Concentrations of $\mathrm{Fe}$ and $\mathrm{Mn}$ in the studied groundwater samples show a distinct relationship with the concentration of As (Table 3). The lack of correlation between dissolved $\mathrm{As}$ and both $\mathrm{Fe}$ and $\mathrm{Mn}$ in the groundwater may result from the precipitation of secondary $\mathrm{Fe}$ and $\mathrm{Mn}$-mineral phases like siderite $\left(\mathrm{FeCO}_{3}\right)$, vivianite $\left[\mathrm{Fe}_{3}\left(\mathrm{PO}_{4}\right)_{2} 8 \mathrm{H}_{2} \mathrm{O}\right]$, pyrite $\left(\mathrm{FeS}_{2}\right)$ and rhodochrosite $\left(\mathrm{MnCO}_{3}\right)$ (McArthur et al. 2001; Aziz Hasan et al. 2009). Reasons for such de-coupling are probably more complex and include re-adsorption of dissolved As on remaining Fe-oxyhydroxides and greater availability and mobility of Fe in sediments compared to As (Dhar et al. 2008). The results show that the concentrations of $\mathrm{As}, \mathrm{Cu}$, $\mathrm{Li}, \mathrm{P}, \mathrm{Mn}$, and $\mathrm{Zn}$ are slightly higher in group I groundwater, suggesting varied water-rock interaction. Unlike other group, arsenic in group I has good statistical correlation with, $\mathrm{Au}, \mathrm{P}, \mathrm{V}, \mathrm{Sr}$ and $\mathrm{Si}$ (Fig. 7). Concentration of $\mathrm{Cu}$ in groundwater is observed in average 4.9, 3.5 and 1.8 $\mathrm{PPb}$ in groups I, II and III, respectively, in the study area. Bioavailability of $\mathrm{Cu}$ in the water influenced by size of the initial $\mathrm{Cu}$ amending, time dependent changes in speciation, and soil humidity, and the retention of $\mathrm{Cu}$ is enhanced 

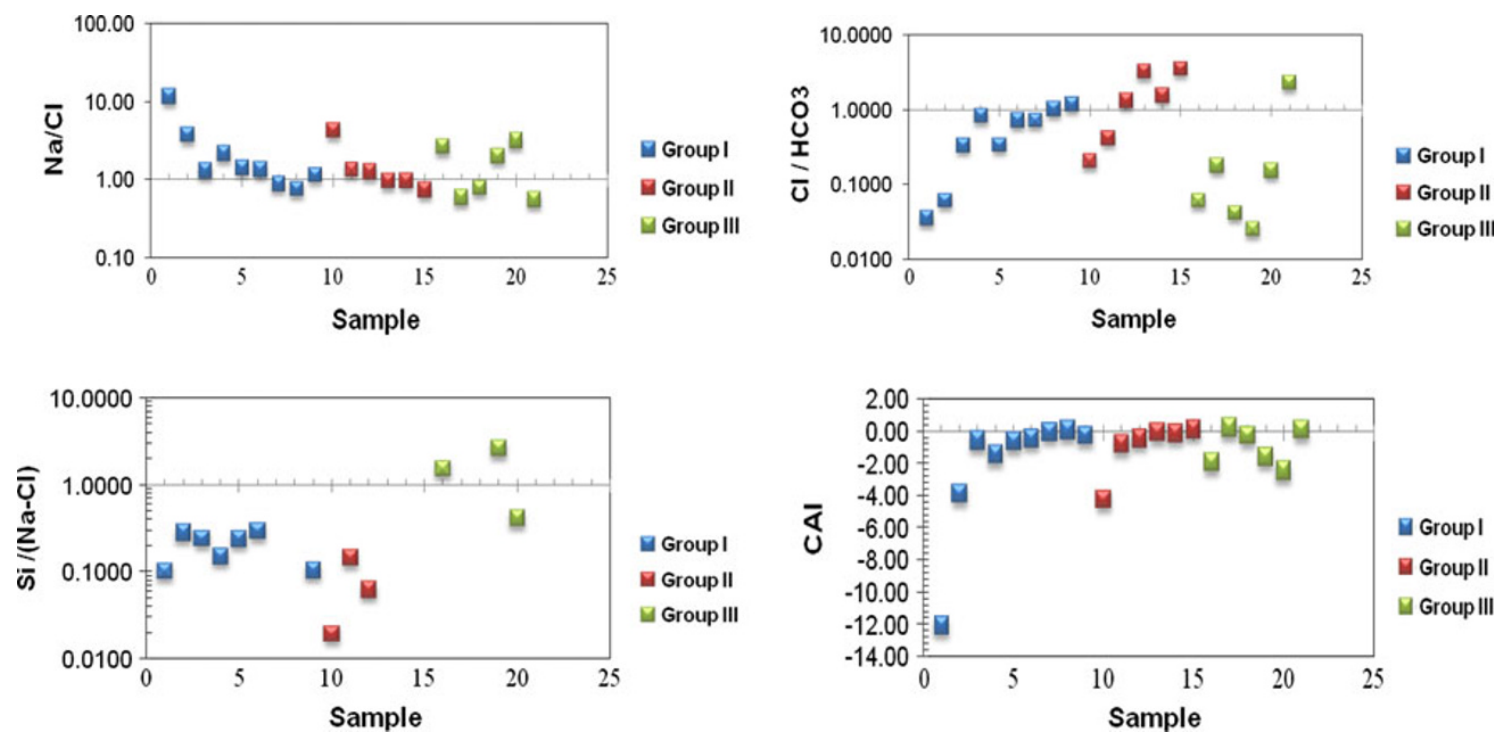

Fig. 5 Major ion relationships $\left(\mathrm{Na} / \mathrm{Cl}, \mathrm{Cl} / \mathrm{HCO}_{3}\right), \mathrm{Si} /(\mathrm{Na}-\mathrm{Cl})$ and $\mathrm{CAI}$ in groundwater of study area
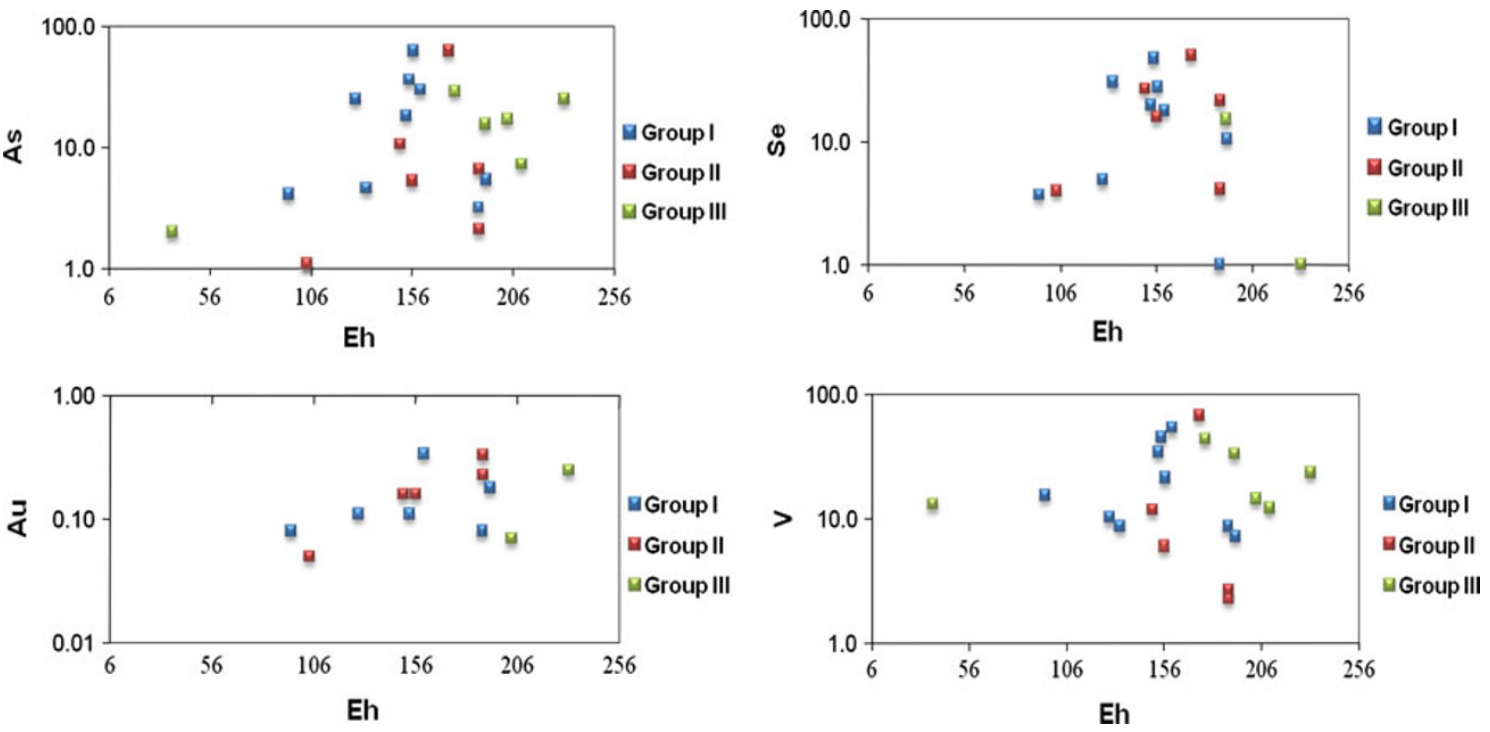

Fig. 6 Variation in measured $\mathrm{Eh}$ and $\mathrm{As}, \mathrm{Au}, \mathrm{V}$, Se for groundwater samples

under stable humid conditions (Petersen et al. 2004). The relationship between major elements in study area is shown in Table 3.

The Au concentration in groups I and II is higher than group III (Table 2) and except for group III, Au concentrations show a linear correlation with As, Se, Sr concentration in group $\mathrm{I}$ and with $\mathrm{B}, \mathrm{Cr}, \mathrm{Cu}, \mathrm{Se}, \mathrm{Sr}$ and $\mathrm{V}$ concentration in group II in groundwater. Under oxidizing, near-neutral and generally low salinity conditions, Au in solution will be in its $3^{+}$valency. Moreover, disproportionation reactions $\left(\mathrm{Au}^{+}\right.$to $\mathrm{Au}^{3+}$ and metallic $\left.\mathrm{Au}\right)$ are a likely process (Fanfani et al. 1996). A number of inorganic ligands have been invoked to account for the complexation of dissolved $\mathrm{Au}$ in oxidizing environments. Hydroxy complexes such as $\mathrm{Au}(\mathrm{OH})_{3}$ and $\mathrm{Au}(\mathrm{OH})_{4}^{-}, \mathrm{Cl}^{-}$complexes such as $\mathrm{AuCl}_{4}^{-}$, mixed hydroxy- $\mathrm{Cl}^{-}$complexes such as $\mathrm{Au}(\mathrm{OH})_{3} \mathrm{CI}^{-}, \mathrm{NH}_{3}$ complexes such as $\mathrm{Au}\left(\mathrm{NH}_{3}\right)_{4}^{3+}$, are among the most important. Other possible complexing species is in equilibrium among the different $\mathrm{S}$-species in solution that play a role in the transport of $\mathrm{Au}$ in these waters (Jaireth 1992). The relative correlation could be observed in these waters between the dissolved Au content and either $\mathrm{Cl}^{-}$or $\mathrm{S}$ (Fig. 7) that may be responsible for migration of Au in study area. 


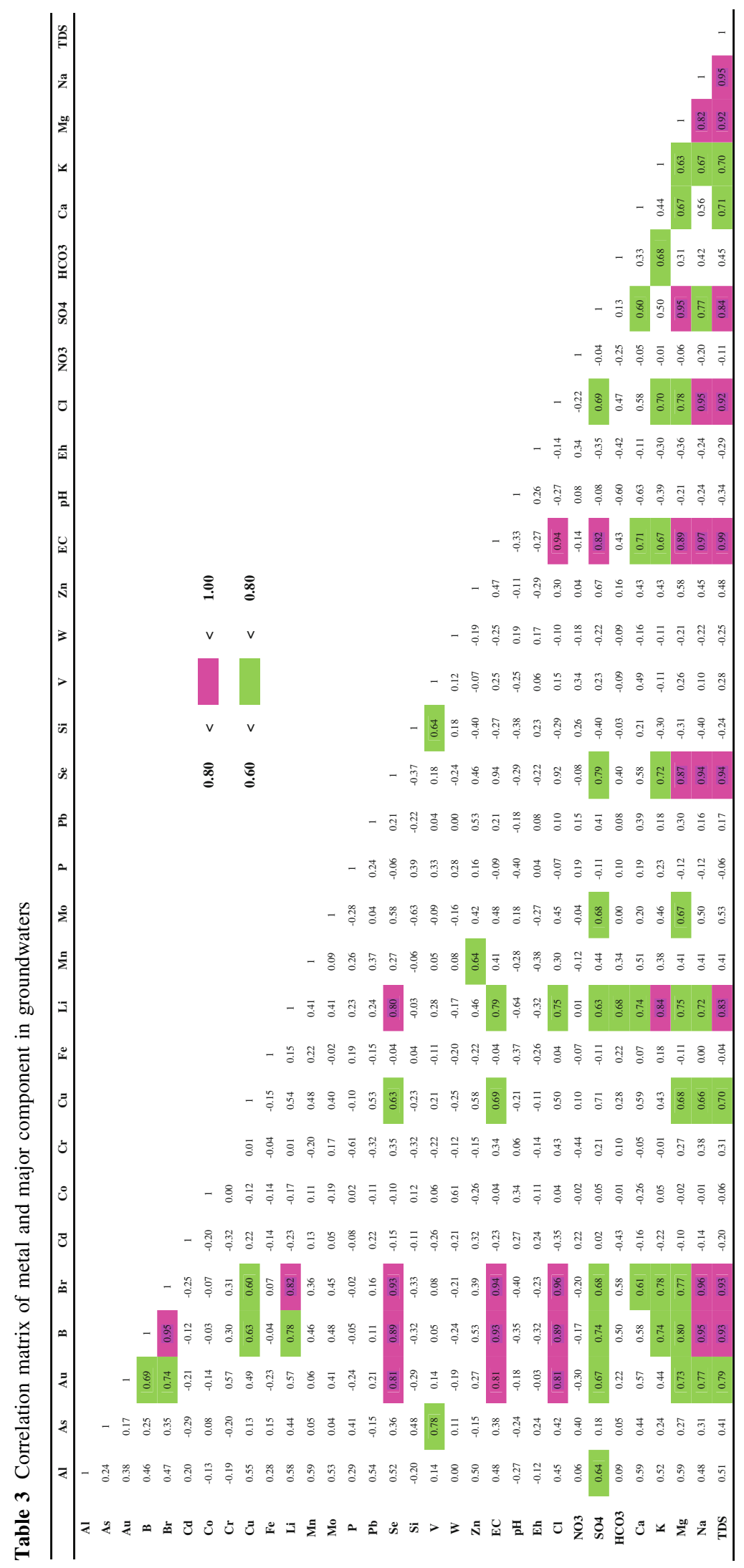



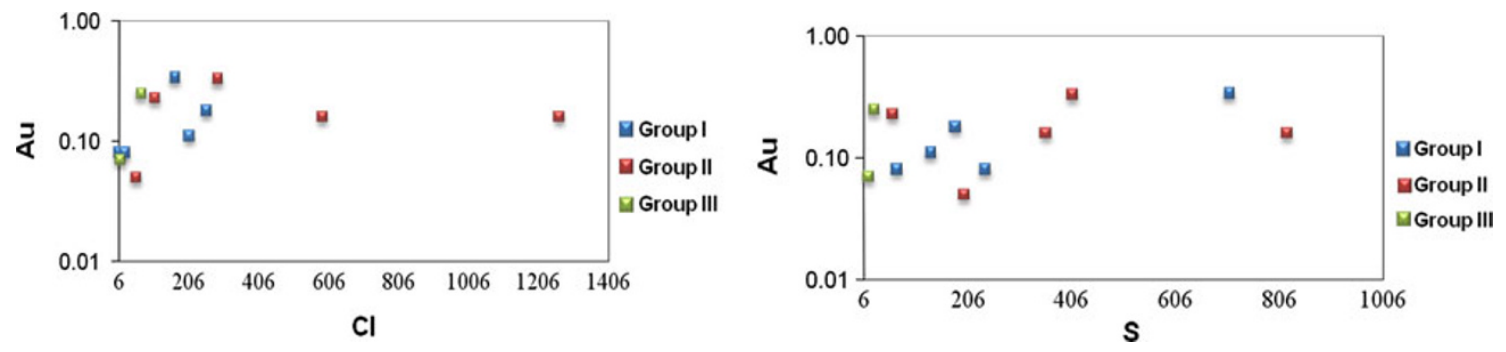

Fig. 7 Relationship between $\mathrm{Au}$ with $\mathrm{S}$ and $\mathrm{Cl}$ for groundwater in study
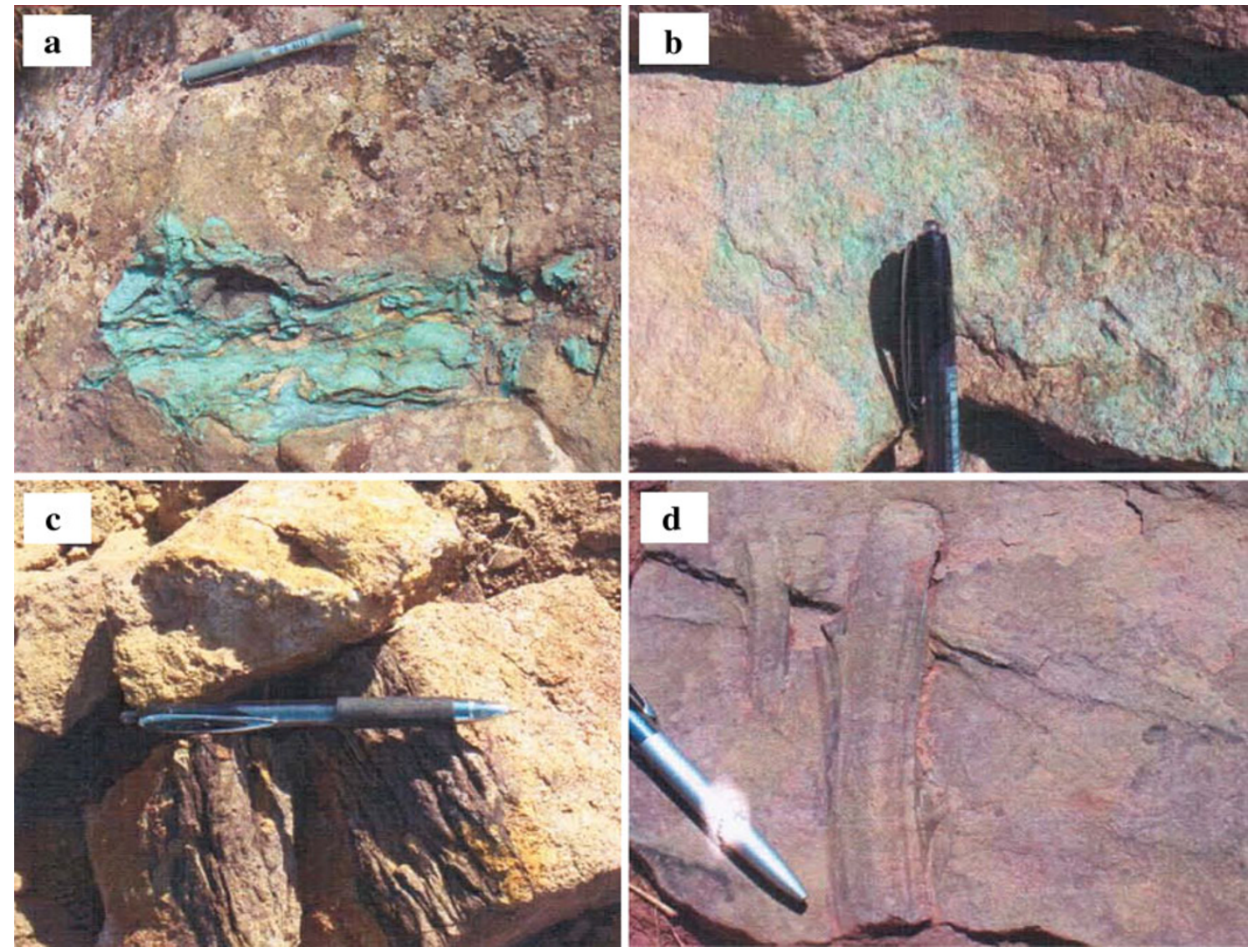

Fig. 8 Sandstone of north Sahand area. a,b Copper mineralization; c iron oxides as limonite; d plant fossils

\section{Conclusion}

In this paper, the hydrogeochemical characteristics of groundwater in around Sahand Mountain, in three sites are described. The $\mathrm{pH}$ of the groundwater in the study area ranged from 6.34 to 8 , indicating an acidic to alkaline nature of the samples in group II, acidic nature in group I and natural in group III. Based on hydrochemical studies, the chemical composition of groundwater differs according to water types. Three types are identified. The hydrochemical types $\mathrm{Ca}-\mathrm{Mg}-\mathrm{HCO}_{3}, \mathrm{Ca}-\mathrm{SO}_{4}$ and $\mathrm{Na}-\mathrm{Cl}$ are characteristics of the studied area. Measured Eh values also indicate that in Group III than Group I and II, the oxide condition is dominant, while in the other groups relative reducing conditions prevail. This could be due to organic matter in sediments of sandstone and conglomerate in these regions (Fig. 8). TDS concentration in group III is higher than other groups, with mean TDS contents of $934 \mathrm{ppm}$. The mixing of silicate weathering and halite dissolution were the probable source of sodium in the study area. The majority of the samples in the group I of samples have freshwater characteristics. The negative CAI values in study area suggest that magnesium and calcium from water are exchanged with sodium and potassium in rock favoring cation-anion exchange reactions. The results show that the concentrations of $\mathrm{As}, \mathrm{Cu}, \mathrm{Li}, \mathrm{P}, \mathrm{Mn}$, and $\mathrm{Zn}$ are slightly 
higher in group I groundwater, suggesting varied waterrock interaction. This result with evidence of coppermolybdenum mineralization and hydrothermal alteration in intrusive rocks from the upstream sample can be justified. Also, due to the presence of copper mineralization as malachite and azurite in basins of I and II groups of samples, concentration of $\mathrm{Cu}$ in groundwater is higher than group III (Fig. 8). There is evidence of gold mineralization in the first two groups.

Open Access This article is distributed under the terms of the Creative Commons Attribution License which permits any use, distribution, and reproduction in any medium, provided the original author(s) and the source are credited.

\section{References}

Acharyya SK, Lahiri S, Raymahashay BC, Bhowmik A (2000) Arsenic toxicity of groundwater of the Bengal Basin in India and Bangladesh: the role of Quaternary stratigraphy and Holocene sea-level fluctuation. Environ Geol 39:1127-1137

Aziz Hasan M, Bhattacharya P, Sracek O, Matin Ahmaed K, Bromssen MV, Jacks G (2009) Geological controls on groundwater chemistry and arsenic mobilization: hydrogeochemical study along an E-W transect in the Meghna basin, Bangladesh. J Hydrol 378:105-118

Berberian M, King GC (1981) Towards a paleogeography and tectonic evolution of Iran. Can J Earth Sci 18:210-265

Dhar RK, Zheng Y, Stute M, van Geen A, Cheng Z, Shanewaz M, Shamsudduha M, Hoque MA, Rahman MW, Ahmed KM (2008) Temporal variability of groundwater chemistry in shallow and deep aquifers. J Contam Hydrol 99:97-111

Fanfani RCL, Edmunds PSWM, Gijbels LVDR (1996) Hydrogeochemical exploration for gold in the Osilo area, Sardinia, Italy. Appl Geochem 10:517-530

Guo H, Zhang B, Wang G, Shen A (2010) Geochemical controls on arsenic and rare earth elements approximately along a groundwater flow path in the shallow aquifer of the Hetao Basin, Inner Mongolia. Chem Geol 270:117-125

Halim MA, Majumder RK, Nessa SA, Hiroshiro Y, Uddin MJ, Shimada J, Jinno K (2009) Hydrogeochemistry and arsenic contamination of groundwater in the Ganges Delta Plain, Bangladesh. J Hazard Mater 164:1335-1345

Jaireth S (1992) The calculated solubility of platinum and $\mathrm{Au}$ in oxygen-saturated fluids and the genesis of platinum-palladium and $\mathrm{Au}$ mineralization in the unconformity-related uranium deposits. Miner Depos 27:42-52

Karimzadeh SA (2005) Petrology and geochemistry of Early Tertiary volcanism of the Mendejin area, Iran, and implications for magma genesis and tectono magmatic setting. Geodin Acta 18:343-362

Mahdavi MA, Amini FA (1988) Geological map of Iran 1:100,000 series-Ahar. Geological Survey of Iran

McArthur JM, Ravenscroft P, Safiullah S, Thirlwall MF (2001) Arsenic in groundwater: testing pollution mechanisms for aquifers in Bangladesh. Water Resour Res 37:109-117

Meyback M (1987) Global chemical weathering of surficial rocks estimated from river dissolved loads. Am J Sci 287:401-428

Moghaddam AA, Najib MA (2006) Hydrogeologic characteristics of the alluvial tuff aquifer of northern Sahand Mountain slopes, Tabriz. Iran Hydrogeol J 14:1319-1329
Mohajjel M, Fergusson CL (2000) Dextral transpression in Late Cretaceous continental collision, Sanandaj-Sirjan zone, western Iran. J Struct Geol 22:1125-1139

Mukherjee A, Bromssen MV, Rcanlon BR, Bhattacharya P, Fryar AE, AzizHasan M, Ahmed KM, Chatterjee D, Jacks G, Sracek O (2008) Hydrogeochemical comparison and effects of overlapping redox zones on groundwater arsenic near the Western (Bhagirathi sub-basin, India) and Eastern (Meghna sub-basin, Bangladesh) margins of the Bengal Basin. J Contam Hydrol 99:31-48

Nabavi M (1976) An introduction to the geology of Iran. Geological Survey of Iran publication, p 109 (in Persian)

Pazand K, Hezarkhani A, Ghanbari Y, Aghavali N (2011) Groundwater geochemistry in the Meshkin shahr basin of Ardabil province in Iran. Environ Earth Sci. doi:10.1007/s12665-011$1131-8$

Petersen AT, Hansen HCB, Nybroe O (2004) Time and moisture effect on total and bioavailability copper in soil-water extracts. J Environ Qual 33:505-512

Pourhosseini F (1981) Petrogenesis of Iranian plutons: a study of the Natanz and Bazman intrusive complexes. PhD Thesis. University of Cambridge, Cambridge, p 315 (also Geological Survey of Iran, Report no. 53)

Raghunath HM (1987) Ground water. Wiley Eastern Limited, New Delhi, p 563

Rango T, Bianchini G, Beccaluva L, Tassinari R (2010) Geochemistry and water quality assessment of central Main Ethiopian Rift natural waters with emphasis on source and occurrence of fluoride and arsenic. J Afr Earth Sci 57:479-491

Rowell DL (1994) Soil science: methods and applications. Longman and Scientific Technical, New York, p 350

Schoeller H (1977) Geochemistry of groundwater. In: groundwater studies-an international guide for research and practice. UNESCO, Paris, vol 15:1-18

Shahrabi M (1985) Geological map of Iran 1:250,000 seriesUrumieh. Geological Survey of Iran

Sharif MU, Davis RK, Steele KF, Kim B, Kresse TM, Fazio JA (2008) Inverse geochemical modeling of groundwater evolution with emphasis on arsenic in the Mississippi River Valley alluvial aquifer, Arkansas (USA). J Hydrol 350:41-55

Smedley PL, Edmunds WM (2002) Redox patterns and trace element behavior in the East Midlands Triassic Sandstone Aquifer, UK. Ground Water 40:44-58

Smedley PL, Knudsen J, Maiga D (2007) Arsenic in groundwater from mineralized Proterozoic basement rocks of Burkina Faso. Appl Geochem 22:1074-1092

Stallard RF, Edmond JM (1987) Geochemistry of the Amazon 3. Weathering chemistry and limits to dissolved inputs. J Geophys Res 92:8293-8302

Tehrani NA, Lotfi M (1978) Geological map of Iran 1:250,000 series-Miyaneh. Geological Survey of Iran

Valles V, Ndiaye MK, Bernadac A, Tardy Y (1989) Geochemistry of waters in the Kouroumari region, Mali: $\mathrm{Al}, \mathrm{Si}$ and $\mathrm{Mg}$ in waters concentrated by evaporation-development of a model. Arid Soil Res 3:21-39

Webster JG, Nordstrom DK (2003) Geothermal arsenic: the sources, transport and fate of arsenic in geothermal systems. In: Welch $\mathrm{AH}$, Stollenwerk KG (eds) Arsenic in ground water: geochemistry and occurrence. Boston Kluwer Academic Publishers, Norwell, pp 101-125

Welch AH, Lico MS, Hughes JL (1988) Arsenic in ground water of the western United States. Ground Water 26(3):333-347 